\title{
Improvement of the photosynthetic activity of Moldavian dragonhead (Dracocephalum moldavica L.) through foliar application of a nitrophenolate-based biostimulant
}

\author{
Stawomir Kocira ${ }^{1,}$, Agnieszka Sujak ${ }^{2}$, Tomasz Oniszczuk ${ }^{3}$, Agnieszka Szparaga ${ }^{4}$, Mariusz Szymanek ${ }^{5}$,Hanna \\ Karakuła-Juchnowicz ${ }^{6}$, Anna Krawczuk ${ }^{1}$, and Karol Kupryaniuk ${ }^{3}$ \\ ${ }^{1}$ University of Life Sciences in Lublin, Department of Machinery Exploitation and Production Process Management, Głęboka 28, \\ 20612 Lublin, Poland \\ ${ }^{2}$ University of Life Sciences in Lublin, Department of Biophysics, Akademicka 13, 20950 Lublin, Poland \\ ${ }^{3}$ University of Life Sciences in Lublin, Department of Food Process Engineering, Doświadczalna 44, 20280 Lublin, Poland \\ ${ }^{4}$ Koszalin University of Technology, Department of Agrobiotechnology, Racławicka 15-17, 75-620 Koszalin, Poland \\ ${ }^{5}$ University of Life Sciences in Lublin, Department of Agricultural Machinery, Głęboka 28, 20612 Lublin, Poland \\ ${ }^{6}$ Medical University of Lublin, Department of Clinical Neuropsychiatry, Głuska 1, 20439 Lublin, Poland
}

\begin{abstract}
Application of biostimulants instigates many physiological processes that enhance nutrition efficiency, abiotic stress tolerance, and quality traits of crops, regardless of their nutrient content. One of such preparations is Atonik which contains nitrophenol compounds naturally occurring in plant cells. Several studies have confirmed its beneficial effect on the growth, development, and improved metabolic activity of plants. Therefore, it seems advisable to investigate the effect of Atonik preparation on the photosynthetic activity of Moldavian dragonhead (Dracocephalum moldavica L.). The reported study was carried out in 2014 in Perespa, Poland. Over the growing season, Atonik was foliar-applied at a dose of $0.3 \mathrm{~L} / \mathrm{ha}(0.1 \%)$ and $0.6 \mathrm{~L} / \mathrm{ha}$ $(0.2 \%)$ by single and double spraying of plants. Chlorophyll content and nitrogen status $(\mathrm{N})$ were estimated by a Chlorophyll Meter SPAD-502 Plus. The foliar application of Atonik was found to improve the efficiency of the photosynthetic apparatus and chlorophyll content in the leaves of Dracocephalum moldavica plants, but the results were dependent on biostimulant concentration and number of its applications, and on the date of measurement. To conclude, Atonik is an environmental-friendly preparation which has a positive impact on the metabolic processes of plants.
\end{abstract}

\section{Introduction}

It is commonly believed today that high yields of crops results from agriculture intensification. However, attempts have been undertaken in recent years to apply preparations that would ensure high yields of highquality crops under minimized use of pesticides and fertilizers. These preparations include, e.g., biostimulants which aside the above benefits are also environmentfriendly. The application of biostimulants accelerates many physiological processes that enhance nutrition efficiency, abiotic stress tolerance, and quality traits of crops, regardless of their nutrient content; and this stimulation effects improvement in crop yield $[1,2,3]$. The use of biostimulants has been reported to influence the metabolic processes in plants by stimulating the synthesis and enhancement of phytohormones, and also to improve their photosynthetic activity $[4,5]$. One of the biostimulants is Atonik preparation which contains nitrophenolic compounds naturally occurring in plant tissues: sodium para-nitrophenolate PNP $(0.3 \%)$, sodium ortho-nitrophenolate ONP $(0.2 \%)$, and sodium 5nitroguaiacolate $5 \mathrm{NG}(0.1 \%)$. Several studies have confirmed the beneficial effect of this biostimulant on the growth, development, and improved metabolic activity of plants. $[6,7,8,14]$. Therefore, it seems advisable to investigate the effect of Atonik preparation on the photosynthetic activity of Moldavian dragonhead (Dracocephalum moldavica L.).

\section{Materials and Methods}

\subsection{Plant materials and growth conditions}

The study was carried out in 2014 in Perespa $\left(50^{\circ} 66^{\prime} \mathrm{N}\right.$; $23^{\circ} 63^{\prime} \mathrm{E}$ ), Poland. The soil type was characterized as Cambic Rendzic Phaeozems. It is alkaline $(\mathrm{pH}$ in $1 \mathrm{M}$ $\mathrm{KCl}$ 7.4-7.5) and rich in phosphorus, potassium, and magnesium. The experiment was established in a randomized block design in four replications with an elementary experimental plot area of $5 \mathrm{~m}^{2}$. The sowing

\footnotetext{
Corresponding author: slawomir.kocira@up.lublin.pl
} 
rate was 15 plants $\cdot \mathrm{m}^{2}$. Moldavian dragonhead seeds were sown in the third 10-day period of April at a depth of 1-1.5 cm, with the spacing of $45 \times 20 \mathrm{~cm}$. over the growing season, Atonik was foliar-applied at a dose of $0.3 \mathrm{~L} / \mathrm{ha}(0.1 \%)$ and $0.6 \mathrm{~L} / \mathrm{ha}(0.2 \%)$ by single spraying (at the 10-12 leaf stage - 20th June) and double spraying of plants (at the 10-12 leaf stage - 20th June and at the beginning of plant blossoming - 4th July). The preparation was applied using a GARLAND FUM 12B battery field sprayer (Lecher LU 120-03) at a pressure of $0.30 \mathrm{MPa}$, using $300 \mathrm{~L}$ of liquid per hectare. The following experimental combinations were investigated: control: where plants were treated with the same volume of water (no biostimulant), 1- or 2-fold spraying with $0.3 \%$ Atonik, and 1- or 2-fold spraying with $0.6 \%$ Atonik. All results from experimental plots were compared to these from the control plots. Tillage of the plants was done following good agricultural practices. No pesticides were used (number of pests did not exceed the thresholds of harmfulness).

The average temperature and rainfall in the soybean growing season are shown in Table 1.

Table 1. Temperature $(\mathrm{T})$ and precipitation during the soybean growing season 2014-2016.

\begin{tabular}{|c|c|c|c|c|c|c|c|c|}
\hline \multirow[b]{3}{*}{ Month } & \multicolumn{6}{|c|}{ Year } & \multirow{2}{*}{\multicolumn{2}{|c|}{$\begin{array}{l}\text { Average } \\
\text { from } \\
2002 \text { to } \\
2013 \\
\end{array}$}} \\
\hline & \multicolumn{2}{|c|}{2014} & \multicolumn{2}{|c|}{2015} & \multicolumn{2}{|c|}{2016} & & \\
\hline & $\begin{array}{c}T\left({ }^{0} \mathrm{C}\right) \\
\min \\
\max \end{array}$ & 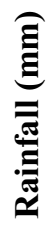 & $\begin{array}{c}\mathrm{T}\left({ }^{0} \mathrm{C}\right) \\
\min \\
\max \end{array}$ & 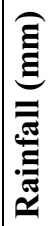 & $\begin{array}{c}\mathrm{T}\left({ }^{\circ} \mathrm{C}\right) \\
\min \\
\max \end{array}$ & 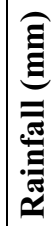 & $\begin{array}{c}\mathbf{T} \\
\left({ }^{\circ} \mathrm{C}\right)\end{array}$ & 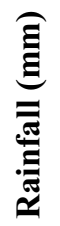 \\
\hline April & $\begin{array}{c}9.4 \\
-6.0 \\
22.7 \\
\end{array}$ & $\ddot{n}$ & $\begin{array}{c}8.2 \\
-1.7 \\
24.3 \\
\end{array}$ & $\ddot{0}$ & $\begin{array}{r}9.2 \\
-1.2 \\
22.6 \\
\end{array}$ & $\begin{array}{l}\forall \\
\dot{0} \\
\dot{0}\end{array}$ & 8.5 & $\frac{\Upsilon}{\gamma}$ \\
\hline May & $\begin{array}{c}13.7 \\
0.5 \\
27.7\end{array}$ & $\begin{array}{l}m \\
\infty \\
\infty\end{array}$ & $\begin{array}{c}12.7 \\
1.5 \\
24.9\end{array}$ & $\begin{array}{l}0 \\
0 \\
0 \\
0\end{array}$ & $\begin{array}{c}13.8 \\
2.6 \\
26.7\end{array}$ & $\frac{n}{6}$ & 12.7 & $\underset{\theta}{\dot{\sigma}}$ \\
\hline June & $\begin{array}{c}16.1 \\
6.7 \\
28.9 \\
\end{array}$ & $\overrightarrow{6}$ & $\begin{array}{c}17.4 \\
6.6 \\
30.5 \\
\end{array}$ & ت & $\begin{array}{c}18.1 \\
4.2 \\
31.5\end{array}$ & $\vec{a}$ & 17.7 & $\begin{array}{l}0 \\
\dot{\infty} \\
0\end{array}$ \\
\hline July & $\begin{array}{l}20.3 \\
10.0 \\
31.0\end{array}$ & $\stackrel{\sim}{\stackrel{+}{O}}$ & $\begin{array}{c}19.6 \\
8.4 \\
33.4 \\
\end{array}$ & $\begin{array}{l}N \\
i n\end{array}$ & $\begin{array}{c}19.5 \\
8.8 \\
31.2\end{array}$ & $\begin{array}{l}0 \\
0 \\
0\end{array}$ & 18.9 & $\overrightarrow{2}$ \\
\hline August & $\begin{array}{c}18.2 \\
6.3 \\
34.0\end{array}$ & $\begin{array}{l}\dot{v} \\
\stackrel{\Xi}{=}\end{array}$ & $\begin{array}{c}21.6 \\
5.6 \\
35.5\end{array}$ & $\begin{array}{l}\dot{v} \\
\ddot{\sim}\end{array}$ & $\begin{array}{c}18.2 \\
7.1 \\
30.7\end{array}$ & $\stackrel{n}{n}$ & 19.4 & $\stackrel{\infty}{\Gamma}$ \\
\hline September & $\begin{array}{c}13.7 \\
3.7 \\
25.8\end{array}$ & $\stackrel{\nabla}{\infty}$ & $\begin{array}{c}15.1 \\
4.2 \\
34.5\end{array}$ & $\begin{array}{l}0 \\
\infty \\
-1 \\
-1\end{array}$ & $\begin{array}{c}15.2 \\
1.6 \\
28.7\end{array}$ & $\frac{\sim}{\gamma}$ & 14.1 & กุ \\
\hline $\begin{array}{l}\text { Average/ } \\
\text { Total }\end{array}$ & 15.1 & 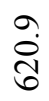 & 15.8 & $\begin{array}{l}0 \\
\dot{m} \\
\tilde{m}\end{array}$ & 17.1 & $\stackrel{9}{\dot{\gamma}}$ & 15.2 & m. \\
\hline
\end{tabular}

\subsection{Photosynthetic activity of plants}

The photosynthetic activity of plants was measured over the entire growing season starting from one week after biostimulant application. For the single spraying combination, the second measurement was carried out in the second term at the appropriate plant development stage. To estimate the actual photochemical activity of PSII in situ, chlorophyll a fluorescence was measured in plants using a pulse amplitude-modulated (PAM) fluorimeter (Mini PAM, Walz, GmbH, FRG, Germany) with a light emitting diode at $650 \mathrm{~nm}$ and a standard intensity $0.15 \mu \mathrm{mol} \mathrm{m} \mathrm{m}^{-2} \mathrm{~s}^{-1}$ PAR (photosyntheticallyactive radiation). A Leaf-Clip holder 2030-B was used in all measurements. Standard settings optimized for measurements with leaf samples at approx. $12 \mathrm{~mm}$ distance between fiberoptics and leaf surface were used for measurements. The parameters listed hereinafter were set. Measuring light: on; Measuring pulse frequency: $0.6 \mathrm{KHz}$; Actinic illumination time: $30 \mathrm{~s}$; Actinic light intensity: 5 (relative intensity 5.5); Actinic light factor: 1.00; LC-WIDTH: 10s; LC INT: 3; IntTemp: on; Light gain: 1.00; Temp. gain: 1.00; Saturating light pulse width: 0.8; Saturation pulse intensity: 8; Electronic signal damping: 2 (0.2s); Measuring light intensity: 8. The Auto-Zero function was applied in order to suppress any unavoidable background signal. All the measurements were done under field condition with the assumption that a photon flux density is below the saturation level. The following fluorescence parameters were measured: F - the present fluorescence yield, M - fluorescence after saturation pulse was applied, Yield $=(\mathrm{M}-\mathrm{F}) / \mathrm{M}, \mathrm{PAR}-$ photosyntheticallyactive radiation, and ETR-electron transfer rate calculated as: $\mathrm{ETR}=$ Yield $\cdot \mathrm{PAR} \cdot \mathrm{ETR}-$ factor; i.e. $\mathrm{ETR}=$ Yield $\cdot \mathrm{PAR} \cdot 0.5 \cdot 0.84$. The standard factor 0.84 corresponds to the fraction of incident light absorbed by a leaf [5]. In turn, Fm' stands for the maximum yield of fluorescence of an illuminated sample. Based on the above information, various parameters of fluorescence were determined which are useful in photosynthesis yield determination. The maximum Photosystem II (PS II) quantum yield of the dark-adapted samples and the effective PS II quantum yield of the illuminated samples, $\mathrm{Y}(\mathrm{II})=\left(\mathrm{Fm}^{\prime}-\mathrm{F}\right) / \mathrm{Fm}^{\prime}=\Delta \mathrm{F} / \mathrm{Fm}^{\prime}$ were determined [9]. The $Y$ (II) parameter corresponds to the fraction of energy which is photochemically-conversed into PS II (consumed during photosynthesis).

Chlorophylls and nitrogen status $(\mathrm{N})$ were estimated by Chlorophyll Meter SPAD-502 Plus (Konica Minolta) (ten plants of each experimental combination). SPAD is the chlorophyll content

\subsection{Statistical analysis}

Data on photosynthetic parameters of four replicates of each combination were subjected to statistical analysis. The Shapiro-Wilk test was performed for the normal distribution of data. The results were analyzed using one-way analysis of variance, ANOVA. The significance of differences between evaluated mean values was estimated by Tukey's test intervals of confidence at a significance level of $p<0.05$. Statistical analysis was performed with Statistica ver. 12 software (StatSoft, Inc.). 


\section{Results and Discussions}

Fluorescence measurements conducted in the first term (measurement I) demonstrated the single foliar application of a $0.1 \%$ solution of Atonik to cause over three-fold increase in photosynthetically-active radiation (PAR) of the plants, compared to double spraying of the biostimulant in the same concentration (table 2). Kocira et al. $[5,12,13]$ reported that single foliar spraying of a biostimulant, based on algae and amino acids (Fylloton) used in a lower concentration, had the most beneficial effect on PAR enhancement. This parameter indicates the amount of energy accumulated by a plant in a specified time of measurement. Result of this measurement obtained in the current study suggests that considering no distinct differences in weather conditions, the differences occurred probably at the molecular level and were additionally affected by the physical status of Moldavian dragonhead plants (energy levels in the photosynthetic apparatus). In addition, an increase in the photosynthetically-active radiation informs indirectly about the consumption of solar energy by plants. The photosynthetically-active radiation (PAR) is linked with the maximum yield of sample fluorescence under natural/field (F) conditions; namely an increase in $\mathrm{F}$ is accompanied by a decrease in PAR. Usually this parameter indicates the fraction of energy that is not consumed in the process of photosynthesis in the course of the experiment.

Results obtained demonstrated a $16 \%$ increase in the effective photochemical yield of PS II (Y (II)) upon the single spraying of $0.1 \%$ Atonik solution, compared to the double spraying of the biostimulant in the higher concentration (measurement II) (table 3). The single spraying of Moldavian dragonhead plants with $0.1 \%$ Atonik solution increased the electron transport rate (ETR) by almost $80 \%$ compared to the control (measurement I). However, an increase in biostimulant concentration to $0.2 \%$ (at the same stage of plant growth) caused over threefold decrease of ETR. In turn, during measurement II the highest value of ETR was determined as a result spraying the plants with Atonik in a higher concentration, regardless of the number of applications. The highest value of ETR was determined in plants during measurement $\mathrm{I}$, when plants of Moldavian dragonhead were at the stage of 10-12 developed leaves, which is indicative of their more intensive growth at this stage than at the stage of blooming.

The foliar application of Atonik preparation caused an increase in chlorophyll content in leaves of Moldavian dragonhead plants in both measurement I and II. This observation confirms findings reported in the study by Kocira et al. [5], where spraying plants of Moldavian dragonhead with a Fylloton biostimulant increased chlorophyll content in leaves. The stimulating effect of Atonik preparation on chlorophyll content increase in plant leaves was also confirmed in investigations conducted with Arabidopsis thaliana, oilseed rape, and common osier [6,8].
Table 2. Effect of Atonik on the PS II chlorophyll fluorescence and photosynthetically-active radiation of Moldavian dragonhead (Dracocephalum moldavica L.) plants.

\begin{tabular}{|c|c|c|c|c|c|c|}
\hline \multirow{2}{*}{\multicolumn{2}{|c|}{ 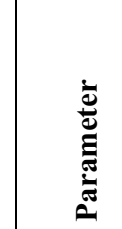 }} & \multicolumn{5}{|c|}{ Experimental combination } \\
\hline & & ن̈ & $\begin{array}{c}\text { Single } \\
\text { spraying } \\
\text { with } \\
\mathbf{0 . 1 \%} \\
\text { Atonik }\end{array}$ & $\begin{array}{c}\text { Double } \\
\text { spraying } \\
\text { with } \\
0.1 \% \\
\text { Atonik }\end{array}$ & \begin{tabular}{|c} 
Single \\
spraying \\
with \\
0.2\% \\
Atonik
\end{tabular} & $\begin{array}{c}\text { Double } \\
\text { spraying } \\
\text { with } \\
\mathbf{0 . 2 \%} \\
\text { Atonik }\end{array}$ \\
\hline \multirow{2}{*}{$\mathrm{F}$} & $\mathrm{I}$ & $399.63 a$ & $422.88 \mathrm{a}$ & $350.75 a$ & $430.25 \mathrm{a}$ & $432.25 \mathrm{a}$ \\
\hline & II & $364.12 \mathrm{a}$ & $342.14 \mathrm{a}$ & $324.29 a$ & $324.00 \mathrm{a}$ & $367.57 \mathrm{a}$ \\
\hline \multirow{2}{*}{ Fm' } & I & $1028.50 \mathrm{a}$ & $1069.25 \mathrm{a}$ & $1473.75 b$ & $843.13 \mathrm{a}$ & $811.88 \mathrm{a}$ \\
\hline & II & $1434.43 \mathrm{a}$ & $1744.71 \mathrm{~b}$ & $1330.71 \mathrm{ab}$ & $1479.43 \mathrm{a}$ & $1204.14 \mathrm{a}$ \\
\hline \multirow{2}{*}{ PAR } & I & $449.25 \mathrm{a}$ & $919.50 \mathrm{~b}$ & $242.63 a$ & $376.00 \mathrm{a}$ & $424.13 a$ \\
\hline & II & $78.57 \mathrm{a}$ & $113.00 \mathrm{ab}$ & $77.00 \mathrm{a}$ & $178.00 \mathrm{bc}$ & $209.85 \mathrm{c}$ \\
\hline
\end{tabular}
measurement at the beginning of plant blossoming.

Means in the same column with different letters are significantly different $(\alpha=0.05)$.

Percival et al. [10] demonstrated chlorophyll content in leaves to be associated with leaf photosynthetic rates. Like in the previous study [5], the correlations between values of SPAD and F-Fm'/Fm' as measures of photosystem II efficiency were weak. The F-Fm'/Fm' ratio is positively correlated to the PSII quantum yield and an indirect measurement of plant physiological status for which the values of $0.8 \pm 0.05$ correspond to highly efficient use of the excitation energy in photochemical processes. In our study, such a value was obtained only upon single spraying the plants with Atonik in the lower concentration (II measurement). In addition, the F-Fm'/Fm' ratios of 0.6-0.8 were associated with SPAD values between 50.5 and 63.8 .

Many authors confirmed the beneficial effect of biostimulants on enhanced intensity of photosynthesis of cultivable plants like Dracocephalum moldavica, basil, rocket, Arabidopsis thaliana, and oilseed rape [5-f7, 11].

Table 3. Effect of Atonik on the photosynthetic and chlorophyll parameters of Moldavian dragonhead (Dracocephalum moldavica L.) plants.

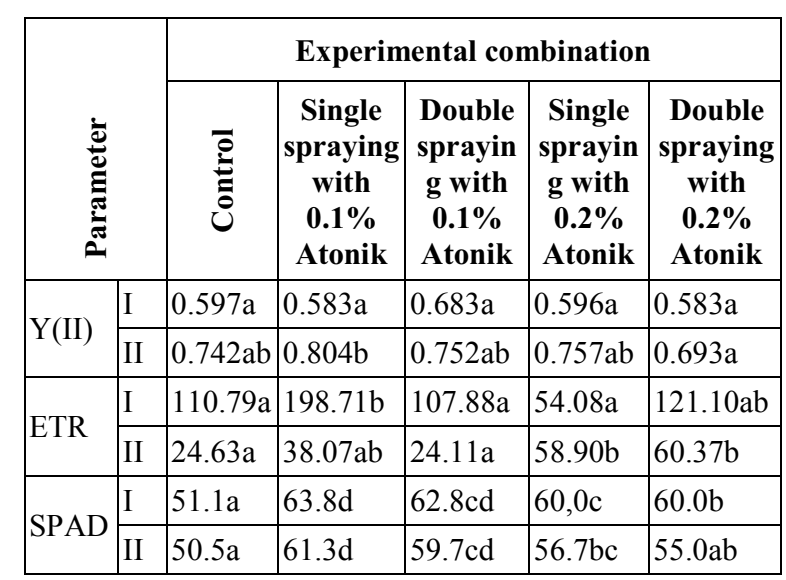

I - measurement at the 10-12 leaf stage; II measurement at the beginning of plant blossoming. Means in the same column with different letters are significantly different $(\alpha=0.05)$. 


\section{Conclusions}

The foliar application of Atonik preparation improved the efficiency of the photosynthetic apparatus and chlorophyll content in the leaves of Dracocephalum moldavica plants, but the results were dependent on biostimulant concentration and number of its applications, and on the date of measurement (growth stage of plants). The photosynthetic activity of Moldavian dragonhead leaves was most positively affected by the single spraying with Atonik preparation in the lower concentration. Foliar application of Atonik preparation increased chlorophyll content in leaves of Dracocephalum moldavica. Atonik was found to be an environmental-friendly preparation which has a positive impact on the metabolic processes of plants.

\section{References}

1. P. Du Jardin, Scientia Horticulturae, 196, 3-14 (2015)

2. A. Kocira, M. Świeca, S. Kocira, U. Złotek, A. Jakubczyk, Saudi Journal of Biological Sciences (2016), https://doi.org/10.1016/j.sjbs.2016.01.039

3. A. Kocira, S. Kocira, M. Świeca, U. Złotek, A. Jakubczyk, K. Kapela, Scientia Horticulturae 214, 76-82 (2017)

4. P. Calvo, L. Nelson, J.W. Kloepper, Plant Soil, 383, 1-2, 3-41 (2014)

5. S. Kocira, A. Sujak, A. Kocira, A. Wójtowicz, A. Oniszczuk, Agriculture and Agricultural Science Procedia, 7, 108-112 (2015)

6. A. Przybysz, H. Gawrońska, J. Gajc-Wolska, Frontiers in Plant Science, 5, 713, 1-15 (2014)

7. E. Borowski, Z.K. Blamowski, Folia Horticulturae, 21, 39-48 (2009)

8. J. Wróbel, A. Woźniak, Biostimulators in Modern Agriculture. Ornamental and Special Plants, in: Łukaszewska, A. (Ed.). Editorial House Wieś Jutra, Warsaw, 47-55 (2008)

9. B. Genty, J.M. Briantais, N.R. Baker, Biochimica et Biophysica Acta, 990, 87-92 (1989)

10. G.C. Percival, I.P. Keary, K. Noviss, Arboriculture and Urban Forestry, 34, 2, 89-100 (2008)

11. R. Janas, Biuletyn Instytutu Hodowli i Aklimatyzacji Roślin, 262, 197-206 (2011)

12. Niemiec M, Sikora J., Szeląg-Sikora A., Kuboń M., Olech E., Marczuk A. Przemysł chemiczny 96(3),685-688 (2017)

13. Niemiec M, Sikora J., Szeląg-Sikora A., Kuboń M., Olech E., Marczuk A. Przemysł chemiczny 96(11),1240-1243 (2017)

14. Biesaga-KościelniakJ., Kościelniak J., Filek M., Marcińska I., KrekuleJ. Machackova I., Kuboń M. Acta Physiol Plant.32(5), 987-995, (2010) 